The Geneva Papers on Risk and Insurance, 21 (No. 79, April 1996), 158-169

\title{
The Precautionary Principle: A Status Questionis ${ }^{1}$
}

\author{
by Herman Cousy* \\ "Learning to face uncertainties and to \\ manage risk might lead to a quantum leap \\ in the human condition $»^{2}$
}

\section{Introduction}

"Where there are threats of serious or irreversible damage, lack of full scientific certainty shall not be used as a reason for postponing cost-effective measures to prevent environmental degradation». These are the by now well-known terms of principle 15 of the Rio declaration on Environment and Development, one of the early international declarations in which the precautionary principle was clearly formulated. The principle was defined in similar terms ${ }^{3}$ by a declaration of Ministers ${ }^{4}$ in Bergen (Norway) in 1990. Already long before 1990, the concept had been known and used in German environmental law (see below, nr. 2). And in November 1987 the principle of precaution had figured in a ministerial declaration of the second international conference on the protection of the

* Professor, Katholieke Universiteit Leuven, Belgium.

1 The author owes thanks to Prof.Dr. Peter Marburger (Trier) for procuring him with an extensive documentation on the German «Vorsorgeprinzip».

2 GIARINI, O., \& STAHEL, W., The Limits of Certainty, facing Risks in the New Service Economy, 2nd revised ed., Kluwer, 1993, p. 9.

${ }^{3}$ «Lorsqu'il existe une menace de dommage grave ou irréversible, l'absence de certitude complète au plan scientifique ne devrait pas être utilisée pour reporter à plus tard les mesures de prévention de la dégradation de l'environnement».

4 The citation is from the Ministerial Declaration of Bergen, May 1990, also reported by Annex 1 to the OECD-document ENV/EC/ECO(91)12, «Faire Face à l'Incertitude», emanating from the Groupe des experts économiques of the OECD Environmental Committee (the OECD document is hereafter cited as «Faire face à l'incertitude»). 
North Sea (London, 1987). Since then the principle has often been mentioned in international declarations and resolutions concerning marine pollution, global warming and toxic waste management ${ }^{5}$. The principle is also mentioned (and explained) in a growing number of national legal texts, first in Germany (see below, nr. 2), but also in other countries ${ }^{6}$.

It was however mainly since its introduction by the (Maastricht) Treaty on the European Union into the text of article 130R of the Treaty of the European Community (E.C. Treaty) that the "precautionary principle" has become more widely known and that the concept receives broad and growing attention. As is well known, the original article 130R, such as it was introduced into the E.C. Treaty by the Single European Act (17 - 28 February 1986), declared that the three major principles of the European environmental policy are (or were) the principle of preventive action, the principle of rectification at source and «the polluter pays" principle. In Maastricht, the precautionary principle was added to the list and more specifically to the principle of preventive action. The separate mentioning of the two principles clearly indicates that in their authors' intention the two principles must have different meanings or contents. In reality the principle of precaution was not simply «juxtaposed» to the other ones but was mentioned in such a place and way ${ }^{7}$ as to suggest that the precautionary principle is indeed a more general principle or an overriding one.

At first, commentators appeared to be somewhat hesitating while explaining the precise meaning and implications of the newly introduced principle ${ }^{8}$. Therefore it may not be completely useless to briefly describe in a first part of this paper the ways in which the meaning of the concept has been gradually clarified. The concept of precaution has been discussed from legal and economic points of view. As was demonstrated by the recent writings and conferences by François Ewald ${ }^{9}$, the concept may prove to be one of major importance, and indeed a concept of paradigmatic value, not only with respect to the development of a policy of environmental protection, but also with respect to the development of a general framework of the law of social and private security (that is: the law of civil liability, of private insurance and of social security). To give a very brief overview and «status questionis" of some of these economic and legal aspects or implications of the concept of precaution, is the object of the second part of the paper.

\footnotetext{
${ }^{5}$ References in the mentionned OECD document «Faire face à l'incertitude», p. 11.

${ }^{6}$ An interesting example is the French «Projet de loi relatif au renforcement de la protection de l'environnement» (modifying the «Code rural») in which the principle of precaution is defined as «le principe selon lequel l'absence de certitude, compte tenu des connaissances scientifiques et techniques du moment, ne doit pas retarder l'adoption de mesures visant à prévenir un risque de dommage grave et irréversible à l'environnement".

7 Speaking about the environmental policy of the European Union, the (new) article 130R, $\$ 2$ of the Treaty says: «It shall be based on the precautionary principle and on the principles of prevention action», etc.

${ }^{8}$ See DEVROE \& WOUTERS, De Europese Unie, Leuven, Peeters, 1995, p. 495-496.

9 CHAUMET et EWALD, «Petite bibliothèque d'actualité. Autour de la précaution», Risques, n 11, 1992, p. 99; EWALD, F., "La véritable nature du risque de développement et sa garantie», Risques, n` 14, 1993, p. 9-47; EWALD, F., "Les limites de la responsabilité et de l'assurance», non published text of a lecture given at the M.C.E. Conference in London, Octobre 1994, and at the Centre for Risk and Insurance Studies of the Katholieke Universiteit Leuven, 10pp.
} 


\section{Origins of the concept of precaution}

The concept of precaution was first explored and used in German environmental law. Already while developing its first environmental action program of 1971, the German Federal Government of that time had considered the "Vorsorgeprinzip" as being one of the fundamental principles of its environmental policy ${ }^{10}$. At first the principle was interpreted as being a rather vague political maxim, meaning something close to "prevention". Much quoted in this respect is the "Umweltbericht 1976 of the German Federal Government", saying that environmental policy does not limit itself to preventing incumbent dangers and restoring the occurred losses; that in addition thereto a truly precautionary environmental policy requires that the fundaments of nature be taken into prudent consideration and protected ${ }^{11}$. According to another well-known 1978 expert opinion (Unweltgutachten) delivered by the so-called «Rat von Sachverständigen für Umweltfragen" ${ }^{12}$, the "Vorsorgeprinzip" requires that environmental aspects should be taken into account in every decision making process, in such a way that not only threatening possible damage be avoided but that also those developments be taken into account which could lead to future endangering of the environment ${ }^{13}$. In some cases the German legislator appears to have failed to clearly distinguish between "prevention" («Gefahrenabwehr») and "precaution» ("Vorsorge», or "Risikovorsorge»14). Such seems to have been the case in the Atomgesetz, according to which a (nuclear) installation can only be authorized when all the precautions which are required by the state of art and of science to avoid resulting damages, have been taken ${ }^{15}$.

An impressive amount of books and articles have contributed to gradually clarify the concept of "Vorsorge». In the literal sense of the term, "Vorsorge" refers to measures which precede (in time) the actual measures of care which should prevent the damage ${ }^{16}$.

${ }^{10}$ ATZPODIEN, "Geltung und Grenzen des Vorsorgeprinzip im Abfallrecht», Neue Zeitschrift für Verwaltungsrecht, 1989, p. 145.

11 «Unweltbericht 1976 of the German Federal Government»: «Unweltpolitik erschöpft sich nicht in der Abwehr drohender Gefahren und der Beseitigung eingetretener Schäden. Vorsorgende Umweltpolitik verlangt darüber hinaus, dass die Naturgrundlagen geschützt und schonend in Anspruch genommen werden" in (see FELDHAUS, G., "Der Vorsorgegrundsatz des BundesImmissionsschutzgesetz», Deutsches Verwaltungsblatt, 1980, p. 133; compare BREUER, "Unweltschutzrecht», in MUNCH, INGO / SCHMIDT-ASSMANN, Besonderes Verwaltungsrecht, (9th edition), Berlijn, 1992, p. 398.

12 The Rat von Sachverständigen für Umweltfragen, Unweltgutachten, 1978, p. 577.

13 «Gefahrenvosorge» is further distinguished from «Resourcenvorsorge». The idea is here that a sufficient quantity of environmental resources should be spared and reserved for future utilisation (one speaks of the "Freiraum-These»). See about this concept also: FELDHAUS, «Die Vorsorgegrundsatz des Bundes Immissionsschutzgesetzes», Deutsches Verwaltungsblatt, 1980, (133), 135.

14 HOPPE, W. \& BECKMANN, Umweltrecht, Juristisches Kurzlehrbuch für Studium und Praxis, 1989, p. 81: «Die Abgrenzung von Gefahrenabwehr und Vorsorge ist haüfig nur schwierig zu treffen».

$15 \& 7$, II, nr. 3 Atomgesetz: «wenn die nach dem Stand von Wissenschaft und Technik erforderliche Vorssorgen gegen Schäden durch die Errichtung und die Betrieb der Anlage getroffen ist». For a discussion, see BREUER, R., "Gefahrenabwehr und Risikovorsorge im Atomrecht", Deutsches Verwaltungsblatt, 1978, 829-839.

16 ATZPODIEN, o.c., p. 420; GERMANN, Das Vorsorgeprinzip als vorverlagerte Gefahrenabwehr, Rechtsvergleichende Studie zur Reinhaltung der Luft, Vienna - New York, Springer Verlag, 1993. 
Vorsorge (or "Risikovorsorge») deals with "not yet danger» ("noch nicht Gefahr») situations: situations where the danger is far away in time or far away in distance, cases where the probability of the occurrence of accidents is low and situations where (e.g.) harmful emissions are without danger to the environment, but could become dangerous while combined with other sources of pollution ${ }^{17}$. "Sorge" or "Gefährenabwehr" is the attitude to be taken in the face of danger and there is "danger" when the occurrence of damage is probable ${ }^{18}$. (Risiko)Vorsorge is the attitude to adopt when there exists only a suspicion of danger ("Gefahrensverdacht»; ein "Besorgnispotential»).

After having been recognised as a basic principle in the area of the environmental law, the concept also became recognized as a basic principle in areas of the law which are protective of other interests such as health ("Gesundheitsschutz») and safety at work («Arbeitsschutz»)19. In the environmental, but also in the other areas, the Vorsorgeprinzip is considered to be not only a firmly established policy-principle ("politische Maxime»), it is affirmed that it is also a legal principle.

\section{The function of the concept of precaution}

In order to situate and understand the concept of "Vorsorge» or "precaution", one must distinguish between two different questions. The first question is under what circumstances and in what kind of situations the problem of having to take "precautionary" measures (as distinguished from "preventive» measures) arises. The second question relates to the contents of the precautionary measures: what does the precautionary attitude actually imply? Will the precautionary principle lead to action or to non-action when one is not certain about the merits of either one of the possibilities?

Let us consider the first of these two questions. Good illustrations of the situations where the hypothesis of precaution arises are found in the field of environmental protection. With respect to both regional and global pollution, it is not always clear (or certain) what is the effect of emissions upon the environment, nor what effects will result from a reduction of those emissions ${ }^{20}$. Regularly cited examples of such situations of uncertainty are the existing lack or shortage of knowledge about the causes of forest deterioration; about the significance and importance of the deterioration of the ozon-layer, the factors which cause this problem and the remedies which could solve it; about the causes of climate change (cfr. the "global warming" problem) and the attitude to be taken; about the effects of dumping (especially radioactive) waste into the high seas. In each of these cases exists a problem of lack or shortage of knowledge, even of scientific knowledge, which makes it unclear which course must be followed. In some cases the knowledge gap relates to the reality and size of the problem; in other cases the problem is that one has no insight into the causal relationship between an apparent damage and a variety of possible causes;

${ }^{17}$ KLOEPFER, M., Umweltrecht, München, Beck, 1989, pp. 76-79.

18 "Gefahr: Risiko bei dem der Schadenseintritt hinreichend warscheinlich ist», see CANSIER, D., «Gefahrenabwehr und Risikovosorge im Umweltschutz und der Spielraum für ökonomische Instrumente», Neue Zeitschrift für Verwaltungsrecht, 1994, Heft 7, p. 542.

19 OSSENBÜHL, F., "Vorsorge als Rechtsprinzip im Gesundheits-, Arbeits- und Umweltschutz», Neue Zeitschrift für Verwaltungsrecht, 1986, Heft 3,161.

20 «Face à l'incertitude», p. 2. 
or the problem can also lie with the fact that one is not certain which course of action will be capable of reducing the observed damage or impairment. All these are situations of «uncertainty» where the need for a precautionary attitude arises.

We are very close here to the concept of «uncertainty» which is used by economists when they distinguish between "risk» and «uncertainty». It is said ${ }^{21}$ that this distinction was first made by F.H. KNIGHT in the nineteen-twenties ${ }^{22}$. Typical for a situation of «risk» is that the probability of the feared accident taking place can be calculated with precision. Characteristic for a situation of "uncertainty» is that such a calculation cannot be made because of the lack of scientific knowledge about the size or the causes or effects of the dangerous situation. Risks are calculable and therefore insurable, uncertainties are not. Another difference between a "risk» and an "uncertainty" is that a risk can be controlled in the sense that there exists sufficient knowledge about causes and effects to prevent the feared event from taking place. By increasing prevention, the risk decreases. The level of prevention is dictated by efficiency-considerations on the basis of a cost-benefit analysis 23 .

In the case of uncertainties however, preventive measures cannot be envisaged because of the unknown character of the risk. If one nevertheless wants to be prudent while facing an uncertain risk, one will adopt a precautionary attitude. As Christian Gollier puts it: precaution is to uncertainty, what prevention is to risk ${ }^{24}$.

\section{Precaution and development risk}

From the preceding considerations we have learnt that it would not be correct to speak of "precaution" (or "Vorsorge») in situations where the possibility and probability of an accident occurring is low, remote, or distant. These situations do not enter into the category or range of situations which can be qualified as being "uncertainties». Uncertainties arise, quite simply, when one does not know, when one is not certain about what happens or what should happen. The next question is whether the so called «development risk» situations belong to (the other extreme of) this range. As is well known, the concept of development risk was introduced at the time when the Council of Europe concept-treaty on product liability and the E.C. product liability directive (1985) were prepared $^{25}$. Article 7, e of the directive allows the producer of a defective product to escape

${ }^{21}$ GOLLIER, Ch., «Le risque de développement est-il assurable?», Risques, 1994, nr. 14, p. 49.

${ }^{22}$ KNIGHT, F.H., Risk, Uncertainty and Profit, Boston, Houghton-Mifflin, 1921.

${ }^{23}$ The level of prevention is considered to be efficient if an increase in prevention efforts causes a rise of the prevention cost which exceeds the expected decrease of the accident cost for the potential victim. Keeping the level of prevention bellow this socially efficient level, constitutes a lack of due care, and in legal terms, a negligence. See: GOLLIER, o.c., pp. 50-51; see also CALABRESI, G., The costs of Accidents: A legal and economic Analysis, New Haven, Yale University Press, 1970, and of course the huge amount of literature which has been developped to refine this fist-rule by the «law and economics»-doctrine in the American and also European legal doctrine (for a very useful overview, see BOUCKAERT,B., \& DE GEEST, G., Bibliography of Law and Economics, Kluwer Academic Publishers, 1992, pp. 168-220 (tort law and environmental regulation) and pp. 313-319 (product liability).

${ }^{24}$ GOLLIER, Ch., o.c., p. 51.

${ }^{25}$ EWALD, «La véritable nature du risque de développement et sa garantie», Risques, 1993, (9), p. 10. 
from liability by proving that the «the state of scientific and technical knowledge at the time when he put the product into circulation was not such as to enable the existence of a defect to be discovered ${ }^{26}$.

Although the courts in the E.C.-Member-States have not yet had a chance to clarify the exact meaning of the "development risk»-defence, there appears to exist a doctrinal tendency to interpret the concept of development risk in a very narrow sense. Authoritative commentators proclaim that the producer of a defective product can only escape from liability by proving that even by virtue of the most advanced state of scientific knowledge existing at the time of the putting into circulation of the product it was absolutely impossible to discover the defect ${ }^{27}$. If such a restrictive interpretation is given to the «development risk» concept, there appears to be little or no room left for the hypothesis of «precaution» 28 . It seems to us that if the very strict conditions of development risk, as required by the above mentioned legal doctrine, are fulfiled, the question what precautionary measures should be taken does not arise, since the precautionary issue arises only when there is some suspicion, (not based on any scientific certainty) of a possible risk. Conversely, if we find ourselves in a setting of facts where the precautionary issue arises (a situation where the possible dangerousness of an activity is suspected but where there is no scientific certainty about the veracity of the suspicion), some might argue that the (very strict) conditions of validity of the development risk defence are not fulfiled. The exact sense of the development risk defence shall have to be fixed by the courts and, since we are dealing with an autonomous European legal concept, by the European Court of Justice.

In its narrowest interpretation the development-risk hypothesis can be considered as an extreme case of uncertainty, where there exists not even any awareness or suspicion of risk or danger and where the difficult choice for a precautionary attitude does not present itself.

\section{Importance of the concept of precaution}

Precaution requires the making of an uninformed choice, but the wrong choice can have consequences which are catastrophic in all the senses of the term: totally unforeseen, affecting a large number of victims, giving rise to an irreversible situation. This is especially so in the example of multiply caused impairment of global eco-systems.

26 According to article $15,1, b$ of the E.C.-directive, Member States may choose not to introduce this means of defence into their national law and thus provide in their legislation that the producer shall be liable even if he proves that the state of scientific and technical knowledge at the time when he put the product into circulation was not such as to enable the existence of a defect to be discovered.

27 TASCHNER, H.C., \& FRIETCH, E., Produkthaftungsgesetz und Produkthaftungsrichtlinie, 2nd ed., 1990, p. 204; but see SCHMIDT-SALZER, J., \& HOLLMANN, Kommentar E. G. Richtlinie Produkthaftung, Band 1; Deutschland, Verlag Recht und Wirtschaft, Heidelberg, 1986, p. 700, nr. 138.

${ }^{28}$ Anyway, if the restrictive interpretation is upheld, the number of actual cases may turn out to be extremely rare. It will indeed not happen very often that the dangerous potentials of a product or activity are completely unknown. One often cites the Thalidomide (Contergan) case as an example of a development risk situation, although it appears that when Thalidomide was brought onto the German market, the product had been banned in France. Can it be readily upheld, under such circumstances, that the conditions for a «development risk» situation were fulfiled? 
Not only is the making of the right precautionary choice a question of extreme importance (since the issue is not the prevention and compensation of accidental damages, but the handling of catastrophes), the number of cases in which the choice for the right precautionary choice arises is large and still increasing. This has to do with the fact that the state of advancement of scientific and technological knowledge has now reached a rather peculiar configuration. As is explained by Ewald ${ }^{29}$, the present-day technological society has come to a point where the development of scientific and technical knowledge is not capable any more at least not in all cases, of assessing, with any reasonable degree of certainty, the risks and dangers which are created by the products, substances, processes and activities which our technological advancement is now capable to produce. The problem originates from the fact that our capability to do things has grown faster than our capacity to fully and scientifically know the accompanying dangers to mankind and environment. A gap has grown between what we know and what we are capable to do, between our awareness of possible dangers and our scientific knowledge which should enable us to avoid them or, in Ewald's words, between «le savoir» and «le pouvoir». Society used to possess the scientific knowledge necessary to master the dangers which the technological progress of the time was able to create. Prudence and due care were obligatory and in most circumstances sufficient to prevent and control the inevitable dangers accompanying the newly introduced techniques of that time. The dangers were sufficiently known to be guarded against. The attitude to adopt was one of translating this awareness and knowledge into the socially desirable degree and level of preventive action.

The present day society can no longer trust the state of advancement of its scientific knowledge. Science, says Ewald, has lost its power of self-control. This leads to an ambiguous situation in which there exists insufficient knowledge about the risks or dangers of any given activity, but where on the other hand prudent measures appear nevertheless to be obligatory: these are «precautionary» measures. Precaution is the prudent answer and attitude to be adopted in a situation of uncertainty about the future risks and dangers of new activities.

The above signalled discrepancy between «le savoir» and «le pouvoir», and thus the occurrence of situations of «uncertainty», are not likely to remain an incidental or transitory phenomenon, but appear rather to become an inevitable feature of our rapidly changing society. While being constantly submitted to unknown and catastrophic risks, the safety of human life and the integrity of nature are constantly threatened. More than ever before safety has therefore become a central and pivotal worry and sollicitude. F. Ewald speaks of a new paradigm, which in the area's of civil liability and social security will govern the 21 st century, the paradigm of safety ${ }^{30}$. Presently safety is threatened by at least three major dangers: global and irreversible environmental impairment, therapeutical accidents, and the «development risk» problem in new products.

While «safety» (or should we perhaps rather say «unsafety») is thus becoming the paradigm of the 21st century, F. Ewald considers «responsability» as the dominating and central principle of the nineteenth century's attitude toward accidental damage, and «soli-

${ }^{29}$ See the writings cited in footnote nr. 9.

30 See references in foornote nr. 9, and especially the reference to the lecture «Les limites de la responsabilité et de l'assurance». 
darity» as the basic model of the organisation of the 20th century's attitude toward unsafety.

19th century individualism considered it as the basic obligation of each individual to take the necessary measures to take care of himself in case of mischief or accidental damage. «Loss should lie where it falls» was the basic and the simple rule of the (simple) law of accidents of that time. Accidental damage must only be shifted when someone has caused damage by his socially unacceptable behaviour, by an insufficient degree of care. Individual persons or households had to take the necessary measures to spread possible losses. The technique for that is insurance, being based on statistically calculable accident rates. Insurance however is voluntary and not compulsory. In the «société assurancielle» the initiative lies with the individual who is supposed to be aware of the risk and capable to take the proper measures (prévoyance).

In the 20th century the paradigmatic principle of «responsability» is replaced by «solidarity». The solidarity is imposed by law and the state assumes the role of organising this system in a compulsory way. The state has become the «état providence» (Ewald). The accidents are of such a nature that they can be reduced in numbers and severity by the adoption of the necessary «prevention».

Facing the uncertainties of the 21 st century, safety becomes the central worry, and since simple shemes such as liability based on fault, insurance and prevention are not capable anymore to adequately handle the problem, «précaution» is the attitude to adopt. The problem is now to further concretize the concept of precaution and to find out ways to decide what exactly a precautionary attitude implies.

\section{The contents of the concept of precaution}

Whereas the exact place and function and importance of the concept of precaution have by now been established, the concrete rules of conduct which are derived from the concept still remain to be formulated. One (possible) attitude or approach to the problem consists in thinking that although we are here dealing with situations of uncertainty there are possibilities to rationalize decisions in such situations, e.g. by applying some gametheoretical insights. An example of this approach is found in the OECD-paper on uncertainty: «Faire face à l'incertitude».

This already cited OECD-position paper makes an interesting attempt to push the difficult rationalisation of the choice of a precautionary attitude a little further forward. The choice which has to be made in front of a situation of «uncertainty» presents itself as a dilemma. Should one, while facing a possibly grave and irreversible danger which is insufficiently known, wait to take preventive action until sufficient knowledge to reduce the danger has been accumulated («réfléchir avant d'agir»), thereby running the risk of a catastrophe or having to resort to a very costly restoration? Or should one in such a situation of uncertainty take preventive action without waiting for the scientific insight and thereby run the risk of making excessive costs of an unnecessary or exaggerated prevention effort ${ }^{31}$ The choice, or the dillemma, is between what is called an ecologically prudent decision

31 The dillemma being particularly delicate in the case of cumulative pollution with possible effects of fundamental changes to eco-systems (Faire face à l'incertitude, p. 4). 
(avoid ecological disaster even at an economically unjustified cost) and an economically prudent decision (postponing antipollution-action until the ecological risk is proven to be non-negligeable), or still put differently, between a strategy of «precaution» and a strategy of «research». The decision is said to be political, but the OECD-paper tries to introduce some more rationality into the decision-making. On the basis of a game-theoretical model the OECD-study comes to the conclusion that first of all research must be stimulated in order to better identify the problem and its solutions and so decrease the divergence of opinions. The question how much «research» and how much «precaution» (anti-pollution measures) is justified must be answered on the bases of an analysis of estimated costs and benefits. Since we are dealing with an uncertainty situation however, the probabilities that have to be taken into account are not objective (based on statistics) but subjective (based on «beliefs» and «ignorance»). This means in concreto that while evaluating probable costs, an estimation will have to be made of the probability of their success: the smaller this probability, the higher is this «cost of uncertainty» (which must be added to the estimated costs of anti-pollution measures). This means that the lower the level of uncertainty, the more the making of precautionary measures will be justified.

\section{The legal approach}

What about the legal approach to problems of uncertainty? Usually the law deals ex post factum with situations of uncertainty, in the context of civil liability litigation. Under traditional tort law, which is based on fault (negligence), there will be normally no liability since foreseeability of damage is an essential element of fault (or negligence) and unknown or uncertain risks do not fulfil this requirement. Even under a system of strict liability (liability without fault), the law hesitates to extend liability to the cases of «development risk». As is well-known, the EC product liability directive refused to come to a definitive decision: the directive does allow the producer to invoke the «development risk» defence (article 7,c of the directive) but does allow the Member States to derogate from this rule. As of now, among all the EC-Member States, only Luxembourg has made use of the option and denied availability of the «development risk» defence to the producer. The French parliament was bitterly divided over the issue ${ }^{32}$. It must however be mentioned that in the opinion of the German legislator of the so-called Gentechnik Gesetz ${ }^{33}$, the precautionary principle required the introduction of a system of (super) strict liability («Gefährdungshaftung») in which the «development risk» defence nor even the «force majeure» defence are available for the defendant ${ }^{34}$. Economic theory however pleads in favour of the development risk defence ${ }^{35}$.

32 For a vivid description and discussion of Senator Fauchon's proposal to deny the development risk defence to the producer, see the already mentioned article by EWALD, «La véritable nature du risque de développement et sa garantie", Risques, 1994, nr. 14, pp. 9-47.

33 Gesetz zur Regelung von Fragen der Gentechnik, 1 July 1990. For further references, see COUSY, H., «A propos de la notion de précaution», Risques, 1995, nr. 21, (149), p. 158.

34 About this legislation see, inter alia, DEUTSCH, E., «Haftung und Rechtschutz in Gentechnikrecht», Versicherungsrecht, 1990, p. 1041; SCHMIDT-SALZER, J., «Die Haftung für das gentechische Restrisiko», Versicherungsrecht, 1990, p. 1193.

35 See e.g. GOLLIER, «Le risque de développement est-il assurable?», Risques, 1993, p. 49 et seq. The development risk hypothesis is based on the concept of uncertainty and can therefore not be treated as the other risks which are linked to the liability of the producer. The characteristic of an 
The confrontation of the law of civil liability with unexpected and unpredictable catastrophes does put the legal system under pressure and leads to some unexpected reactions of judges and even of legislators. This is clearly illustrated by the phenomenon of the so-called "retroactive liability» decisions. Liability decisions are always "retroactive» in some respects, since the judgement about the liability is made after the damage to the victim has taken place. By "retroactive liability decisions» are meant those decisions in matters of civil liability which are made on the basis of liability rules that did not exist at the moment where the activity was taking place. One must admit that giving a retroactive effect to legal rules constitutes a grave departure from basic fairness rules and also from basic legal principles such as the principle of non-retroactivity of legal rules.

In some cases of unforeseen and catastrophic damages, court decisions have departed from established legal rules on evidence and causation. The D.E.S. cases are a good example. In the case of «Sindell v. Abott Laboratories» the California Supreme Court has, ex post factum, introduced the concept of «market share liability», stating that in cases where a drug caused harmful side effects after a long period of time so as to make the tracing back of the specific prescription drug to an individual manufacturer impossible, the different defendants-manufacturers should carry a prorata share of the liability according to their market share ${ }^{36}$. In a recent decision, equally delivered in a D.E.S.-affair, the highest court of the Netherlands, the "Hoge Raad», allocated liabilities on the basis of a rule $^{37}$ which did not exist at the time of the manufacturing of the drug ${ }^{38}$.

insurable risk is that its probability can be measured with precision. Uncertainties are unmeasurable and thus uninsurable. Gollier cites the difficulty to make an adequate cost-benefit analysis of the postponement of the introduction of a new pharmaceutical product. If it is possible to calculate the cost of the loss of human lives which is caused by this postponement, it is not possible to measure the benefit which result from such postponement in terms of the reduction of uncertainty. The progress of science is far too erratic for such prediction (GOLLIER, o.c., p.54).

Rendering the producer liable (even) in the case of development risk (removing the «development» risk defence from the producer who is strictly liable) will not enchance the compensation of victims but rather diminish and deteriorate it. Imposing «super strict liability» (strict liability without posiibility to invoke the development risk defence), will in the absence of adequate and durable liability insurance, lead to bankruptcies of the producers and thus further hinder compensation of product victims. In addition, imposing «super strict liability» will hinder innovation. If innovative products will be manufactured at all, it shall have to be in small and under capitalized business units. Strict liability for development risk will eventually lead to «super precaution» and excessive costs.

Facing the impossibility of adequately control development risks, Gollier raises the question whether it would not be better to leave the decision for new products (accompanied by a development risks) to the consumer. Ewald comes to a similar conclusion and suggests some form of shared liability in the case of scientifically unknown risks: unjust is the society where a person can participate in the benefits of modern society while being allowed to systematically put the burdens of these advantages on the other ones. Ewald, "La véritable nature du risque de développement», cited in note 8 . The basic idea appears to be that the risk and burdens of an insufficient advancement of science should be shared by society as a whole. Imposing strict liability on producers of new products is in this vision, not the right way to do so. series).

36 Sindell v. Abott Laboratories, Supreme Court of California, March 20, 1980 (607 Pac.Rep., 2d

${ }^{37}$ Hoge Raad, 9 october 1992, (published in) Rechtspraak van de Week, 1992, nr. 219, pp. 10711086; Tijdschrift voor Consumentenrecht, 1992, 241-258.

${ }^{38}$ In casu the new rule had not even entered into force at the time of the decision of the court, but was applied an anticipatory way, in view of the imminent entering into force of the relevant articles of the new Dutch Civil Code. 
Still more remarquable is the fact that even legislators have at times reverted to imposing retroactive liabilities, especially with respect to the liability for the cleaning costs of historic waste sites. Not only in the well known American CERCLA legislation, but also in many other countries, rules have been promulgated by virtue of which administrative agencies can recover cleaning up-costs from persons on the basis of not-previously established liability rules.

It is strongly suggested that such departures from basic rules and principles must be considered as temporary and occasional departures from legal orthodoxy, which are only acceptable because of the exceptionnal and «catastrophic» nature of the situation. Even when they arise out of catastrophic situations, liabilities should be organised on the basis of preexisting legal rules. The crux of the problem is however to know what the precise contents of these rules must be.

Still another way in which the law of civil liability is led to change its most sacred basic principles, while confronted with situations of uncertainty, is that the requirement of causal relationship between tortfeasor and damage is relinquished. The German «Gentechnik Gesetz» for instance introduces a presumption of causality (Ursachenvermutung) and thus a reversal of the burden of proof with respect to the causal relationship ${ }^{39}$.

The law has much less experience with handling situations of uncertainty «ex ante». Only recently legislators and other rule-givers have been consciously confronted with the question whether, and if so what, precautionary measures should be imposed in situations of uncertainty, especially (but not exclusively) in the field of environmental impairment. At present a growing number of examples of legal rules, which are clearly inspired by precaution-related considerations, can be cited. An interesting example is found in the German legislation on genetic technology (again). Characteristic for this legislation is the way in which its field of application is extended to all the substances which have been genetically modified, without distinguishing (as is done in American and Japanese law) between dangerous and non-dangerous activities. The choice for such a «horizontal» (rather than «vertical») approach (or for a «process» - rather than «product» approach) $)^{40}$ is expressly justified by reference to the «Vorsorgeprinzip». This principle explains why a system of control is imposed even upon those manipulated substances, which according to the «Stand von Wissenschaft» do not present any threat to the integrity of man or nature. The «Vorsorgeprinzip» requires the identification of so called basic risks: basic risks are those activities, (even) those (entire) technologies, of which the «Stand von Wissenschaft» does not allow to identify with certainty the inherent dangers. No need to stress that the identification of «basic risk» categories will be of extreme importance. And equally delicate will be the decision by which a new product, process or technology is considered sufficiently well-know by the development of science to be withdrawn from the «basic risk» category.

${ }^{39}$ LANDSBERG \& LÜLLING, «Die Ursachenvermutung und die Auskunftansprüche nach dem neuen Umwelthaftungsgesetz», Wirtschaftsrecht, 1991, 479.

40 Compare WAHL \& MELCHINGER, «Das Gentechnikrecht nach der Novellierung», Juristen Zeitung, 1994, (974), 976. 


\section{Summary and concluding remarks}

It has taken some time before a clear and unanimous interpretation emerged of both the function and (especially) the contents of the concept of precaution and the eprecautionary principle». Ever since the concept first appeared in German legal and political texts about the environmental policy, a (by now unaninıous) understanding has grown about the function and paradigmatic importance of the concept. Economic theory and ethics made it clear that precaution is the prudent attitude to be adopted in face of a situation of uncertainty (the uncertainty being in this context clearly differentiated from the calculable «risk»). It appears that the discussion about the regime of civil liability to be applied to «development risk» situations is not yet settled in the different legal area's. And legislators and governments are slowly searching for ways to concretize the rules of conduct to be derived from the principle of precaution. Social sciences undoubtedly still have an important role to play in the preparatory developnient and formulation of theory in this field. In the mean time, the decision for precaution remains to a large extent political. In our search for guidance among the general legal principles, a comparison jumps to the mind. Preacaution, as was said before, is a modern modality of due care, of prudence, a concept which is well known in the civil law, more precisely in the traditionnal law of civil liability. Precaution dictates the prudent attitude to be adopted in front of uncertainty. As is the case in general tort law, the legal concept of due care does not dictate a priori a certain concrete course of action. Due care and prudence are «open terms» which refer to extralegal rules of behaviour, which the reasonable man is expected to submit to. In order to help judges and legislators in their appreciation of the concrete requirements of (this very particular form) of due care, it is important that social sciences continue their efforts of rationalization of a (prima facie very difficult) decision in front of the dilemma of precaution. 